\title{
STUDIES ON THE EFFECT OF SOME DORMANCY BREAKING AGENTS ON BUD BEHAVIOUR AND YIELD OF LE-CONTE PEARS
}

\author{
Samra, N. R.; M. I. El-Kady and A. M. Shalan \\ Pomology Dept. Fac. Agric. Mansoura Univ., Egypt.
}

\begin{abstract}
This investigation was carried out during the seasons of 2006 and 2007 to study the effect of some dormancy - breaking chemicals on bud constituents, bud break, flower fire blight infections, fruit set and yield of "Le Conte" pear trees. The data revealed that, spraying Le-Conte pear trees at $1^{\text {st }}$ February with Dormex at $1 \%+$ mineral oil at $3 \%$ was effective for hastening the date of bud burst, enhanced the bud burst percentage and gave pronounced effect on bud constituents, flower fire blight infections, fruit set and yield. Furthermore, spraying Le-Conte pear trees with mixture of Dormex at $1 \%$ and mineral oil at $3 \%$ is an economic treatment than the use of hydrogen cyanamide alone at $4 \%$ as recommended which is rather expensive under the Egyptian conditions.
\end{abstract}

\section{INTRODUCTION}

Dormancy is a phase of development that occurs annually in deciduous fruit trees. Release of dormancy requires accumulated chilling during winter, followed by a rise in temperature in spring (Fuchigmi et al., 1982). The major one of economic production of deciduous fruit trees in subtropics and tropics is the insufficient period of chilling temperature. In this respect, inadequate chilling may result in poor and uneven bud break, reduced and delayed foliage development, sparse bloom, abnormal flower development, poor fruit set and / or early growth cessation (Erez, 1987).

Pear trees are one of the important fruit crops grown in Egypt, facing certain problems concerned with their production. As for "Le Conte" pear trees, one of these is delaying and irregular blooming. Late blooming coincides with weather period favorable for the blight infections and fruit shedding (Stino, 1987). The insufficient winter chilling leads to delayed foliation, poor bud break, delayed and prolonged blooming period (Erez, 1987). On the other hand, early flowering is desirable not only for fruit production, but also to make the pear trees less susceptible to damage by fire blight.

The total cultivated area of pear in Egypt reached about 8394 feddan, with an total production about 40498 ton according to the last statistics of the Ministry of Agriculture (2005).

Dormancy breaking agents have been used in warm regions for controlling bud break of pears trees, where the chilling requirements are not sufficient naturally. Some chemicals have been tried to accelerate bud burst such as thiourea (Sourial et al., 1993); hydrogen cyanamide and mineral oil (Stino, 1997) and potassium nitrate (Shahin et al., 1997). 
Changes in endogenous bud substances which may play a role in breaking dormancy have not been accurately determined (Ramina et al., 1995) and also the flower fire blight infections. Therefore, the purpose of the present investigation was to study the effect of some dormancy - breaking chemicals on bud constituents, bud break, flower fire blight infections, fruit set and yield of "Le Conte" pear trees.

\section{MATERIALS AND METHODS}

The present study was carried out during two successive seasons 2006 and 2007 on "Le Conte" pear to evaluate the effect of Dormex (hydrogen cyanamide $49 \%$ ), mineral oil and the commercial fertilizer AgroTop NPK (4-5-40) as a dormancy breaking chemicals on bud break, flower fire blight infections, fruit set, yield and fruit quality of "Le Conte" pear trees.

"Le Conte" pear (Pyrus communis L. x Pyrus pyrifolia N.) trees were fourteen years old, budded on Pyrus communis rootstock, spaced at 5 meters apart grown in sandy soil under drip irrigation system and modified central leader trained in a private orchard at El-Katatba city, Monifia Governorate.

Forty eight trees, almost uniform in growth and in good physical condition were selected for this study. Treatments were replicated three times each replicate represented by two trees in a complete randomized block design to presente the following treatments as follows:

1) Dormex at $1 \%$.

2) Dormex at $1 \%+$ Mineral oil at $3 \%$.

3) Dormex at $2 \%$.

4) Dormex at $2 \%+$ Mineral oil at $3 \%$.

5) Agro-Top (NPK, 4-5-40) at 4\%.

6) Agro-Top (NPK, 4-5-40) at 4\% + Mineral oil at $3 \%$.

7) Mineral oil at $3 \%$.

8) Control (sprayed with water).

Pear trees sprayed on $1^{\text {st }}$ February and Super Film at $0.1 \%$ was used as a surfactant in all treatments.

In each growing season, four main branches as uniform as possible were chosen at the four cardinal points of each experimented tree, tagged and the number of buds on these branches were counted before treatments. In all seasons, the number of bursted buds, the developed flower and leaf buds and infection flowers by fire blight were counted and expressed as percentages. The percentage of fruit set was also calculated using the total number of flowers per each chosen branch for the different treatments and expressed as percentages.

To study the effect of the treatments on bud total sugars, total phenols and total amino acids in the buds, samples of ten bud / treatment were removed from each tree at different positions after 15 days from the spraying date. A part of each bud sample was saved fresh, whereas the rest was weighed and dried at $65^{\circ} \mathrm{C}$ in oven till a constant weight, then the following parameters in buds were determined and analyzed as following: 
A) Total soluble Sugars:

Total soluble sugars were determined by using phenol $18 \%$ and sulphoric acid $96 \%$ and the absorbance was recorded with spectrophotometer at $490 \mathrm{~nm}$, according to the method described by (Sadasivam \& Manickam, 1996).

B) Total free amino acids:

Total free amino acids were extracted with $80 \%$ ethanol and determined according to the method of (Van Loon \& Van Karmen, 1967) with certain modifications by (Duby \& Rani, 1989a,b).

C) Total phenols:

Total phenols were extracted with $80 \%$ ethanol in boiling water bath and determined according to the method of (Mazumdar \& Majumder, 2003).

Le Conte" pear fruit were harvested at approximately 135 to 147days from full bloom, when the average of fruit firmness reached about 14-15 lb.in 2 and when soluble solids in fruit juice reached about $13-14 \%$ according to (Swindeman, 2002).

Yield per each treatment was recorded as $(\mathrm{kg})$ fruits per tree by counting number of fruits per tree multiplied by average fruit weight. Statistical analysis:

The present data was statistically analyzed according to the methods described by (Snedecor and Cochran, 1980) and the means were compared statistically using Duncan's multiple range at $5 \%$ level of probability.

\section{RESULTS AND DISCUSSION}

The effect of Dormex, Mineral oil and Agro-Top on bud dormancy and yield of "Le-Conte" pears are presented as follow:

I. Effect on number of days from spray to bud burst and bud burst percentage:

The effect of different dormancy breaking agents on the percent of bud burst of Le-Conte pear trees during the seasons of 2006 and 2007 are presented in Table (1). It is clear from this table that all treatments used significantly increased the percent of bud burst than the control. Dormex at $1 \%$ or $2 \%$ with mineral oil at $3 \%$ hastened bud break since the buds sprouted by 23 and 24.5 days after treatment. These treatments hastened the bud burst earlier than using Dormex alone. Yet, using mineral oil alone at $3 \%$ sprouted the buds later than Dormex, but earlier than the untreated trees which induced bud break by about 41 days after the time of spraying. These results go in line with those reported by Mann et al., (1994) which found that Dormex treatments advanced bud burst by 2 weeks in pear trees Cv. Baggugosha. Also, Mokhtar et al., (1994) reported that hydrogen cyanamide application resulted in an early bud break of pear trees. Furthermore, Gabr, (1996) found that spraying Le Conte pear trees with Dormex caused an earlier bud break by 12-15 days. At least, Harmender and Mann, (2002) showed that spraying pear Cv. Pathernakh trees with Dormex at 1, 2, 3 and $4 \%$ and thiourea at 1 and $2 \%$ advanced bud burst by 10 days. 
Table (1): Effect of Dormex, mineral oil and NPK on number of days from spray to bud burst and bud burst percentage.

\begin{tabular}{|l|c|c|c|c|c|c|}
\hline \multirow{2}{*}{ Treatment } & $\begin{array}{c}\text { Number of Days from spray } \\
\text { to bud burst }\end{array}$ & \multicolumn{4}{c|}{ Bud burst\% } \\
\cline { 2 - 7 } & $\mathbf{2 0 0 6}$ & $\mathbf{2 0 0 7}$ & Mean & $\mathbf{2 0 0 6}$ & $\mathbf{2 0 0 7}$ & Mean \\
\hline Dormex 1\% & 29 & 27 & 28 & 94.63 & 95.67 & 95.15 \\
\hline Dormex 1\%+ Mo 3\% & 24 & 22 & 23 & 100.00 & 100.00 & 100.0 \\
\hline Dormex 2\% & 30 & 27 & 28.5 & 98.13 & 99.17 & 98.65 \\
\hline Dormex 2\% + Mo 3\% & 25 & 24 & 24.5 & 97.47 & 96.47 & 96.97 \\
\hline Mineral oil at 3\% & 35 & 32 & 33.5 & 85.62 & 90.30 & 87.96 \\
\hline NPK at 4\% & 31 & 29 & 30 & 95.87 & 95.87 & 95.87 \\
\hline NPK at 4\%+ Mo 3\% & 32 & 29 & 30.5 & 92.43 & 92.43 & 92.43 \\
\hline Control & 42 & 40 & 41 & 65.90 & 77.60 & 71.60 \\
\hline L.S.D at 5\% & 1.73 & 1.73 & 1.73 & 1.32 & 1.51 & 1.42 \\
\hline
\end{tabular}

Abbreviation: NPK = Commercial fertilizer named Agro-Top (4-5-40)

MO = Mineral oil named folk oil.

Concerning, the effect of treatments on the percent of bud burst the data showed a positive correlation between bud burst percentage and Dormex concentration. Since Dormex at $2 \%$ significantly increased the bud burst in pear trees than those sprayed with $1 \%$. Yet, Dormex at $1 \%+$ mineral oil at $3 \%$ treatment gave the highest significant effect in this respect since, the percent was about $100 \%$ as means of two season. This may be due to the superiority of Dormex to increase bud peroxidase activity and decrease catalase one that the inhibited effect on catalase activity causes arise in $\mathrm{H}_{2} \mathrm{O}_{2}$ content and an increase on peroxidase activity in the treated buds. This is turn keeping NADP in an oxidized form which could lead to activate the pentose-phosphate pathway. This activation inducing bud break and subsequent intensive growth after bud break, (Kurado et al., 1990 and Nir and Lavee, 1993). Moreover, cyanamide stimulated the production of cytokinins in the bud which appears to be an alternative to the root system as a source of cytokinin during rest termination and may act as an initiator of growth, (North et al., 1990). In the same line, (Hegazi et al., 1999) found that hormone contents in the floral buds were increased with the application of Dormex and the levels of IAA and $\mathrm{GA}_{3}$ were highest at 15-17 days after spraying date. Generally, bud burst seems to be controlled by the balance between plant hormones rather than a single one. Also, breaking of dormancy was not dependent on the reduced bud level of endogenous ABA, but rather on an accumulation of endogenous stimulators Also, Foot (1987) reported that Dormex penetrates in bud scales, gets absorbed in buds and initiates the processes leading to bud break. Our data go in line with those reported by (EL-Sheikh, 2000 and Harminder \& Mann, 2002).

Spraying pear trees with NPK alone or with mineral oil also increased the percentage of bud burst than the control, but the effect of these treatments was almost lower than Dormex at $1 \%$ with mineral oil at $3 \%$ treatment. Yet, NPK at $4 \%$ alone gave a higher effect on bud burst percentage than when mixed with mineral oil or the control. Since, the bud burst due to this treatment was about $95.87 \%$ as a mean of two seasons. That is due to that NPK alone resulted in significant increase in sorbitol 
concentration. While, the effect of NPK mixed with mineral oil treatment depressed sorbitol level which could play a role in bud break through its effect in increasing osmotic potential in bud tissues. It is well known that sorbitol is the most widely distributed poly sugar in nurture, (Rashad, 1993). Moreover, Nonhebel et al. (1993) reveled that $\mathrm{N}$ - supply leads to an increase in amino acids synthesis, for example tryptophan, which is directly related to IAA synthesis. Furthermore, $\mathrm{K}$ ions play an important role to adjust and keep an osmotic potential in bud tissue and $P$ is an essential element for phospholipids and lenolic acid in structure of plasmalema membranes (Erez et al., 1997).

On the contrary, mineral oil at $3 \%$ treatment gave the lowest effect in this respect. Since, the percent attributed due this treatment was about $88 \%$ as a mean of two seasons. This result could be due to the effect of mineral oil on decreasing the activity of catalase, (Nir \& Lavee, 1993). The obtained data are in harmony with those reported by (EL-Sabrout, 2005 \& Tawfik et al., 2002).

\section{Effect on the percent of vegetative and floral buds:}

Data from Table (2) indicated that the control showed a higher percent of vegetative buds. Since, it presented about $25.15 \%$ as a means of the two seasons. Yet, mineral oil alone at $3 \%$ gave a lower percent of vegetative buds comparing with the other treatments.

Likewise, NPK at $4 \%$ with mineral oil at $3 \%$ reduced the vegetative buds percentage while, Dormex at $1 \%$ alone or with mineral oil at $3 \%$ were more effective in diminishing the percentage of vegetative buds than that which was obtained from Dormex at $2 \%$ alone or with mineral oil. These results were in the same trend in both seasons.

Referring to the effect of dormancy-breaking agents on floral bud percentage, it is obvious from Table (2) that all treatments used increased the floral bud percentage than the control. AS will as, Dormex application at $1 \%$ with mineral oil at $3 \%$ gave a higher significant effect for increasing the floral bud percentage than the other treatments used or the control.

Table (2): Effect of Dormex, mineral oil and NPK on vegetative and floral bud percentages.

\begin{tabular}{|l|c|c|c|c|c|c|}
\hline \multirow{2}{*}{ Treatment } & \multicolumn{3}{|c|}{ Vegetative bud\% } & \multicolumn{3}{c|}{ Floral bud\% } \\
\cline { 2 - 7 } & $\mathbf{2 0 0 6}$ & $\mathbf{2 0 0 7}$ & Mean & $\mathbf{2 0 0 6}$ & $\mathbf{2 0 0 7}$ & Mean \\
\hline Dormex 1\% & 9.05 & 10.59 & 9.82 & 85.58 & 85.08 & 85.33 \\
\hline Dormex 1\%+ Mo 3\% & 7.03 & 6.94 & 6.99 & 92.97 & 93.06 & 93.02 \\
\hline Dormex 2\% & 17.48 & 18.70 & 18.09 & 80.65 & 80.47 & 80.56 \\
\hline Dormex 2\% + Mo 3\% & 13.06 & 11.83 & 12.45 & 84.41 & 84.64 & 84.51 \\
\hline Mineral oil at 3\% & 1.89 & 2.33 & 2.11 & 83.73 & 87.97 & 85.85 \\
\hline NPK at 4\% & 19.64 & 19.78 & 19.71 & 76.23 & 76.09 & 76.16 \\
\hline NPK at 4\%+ Mo 3\% & 3.59 & 3.42 & 3.51 & 88.84 & 89.01 & 88.91 \\
\hline Control & 19.81 & 30.49 & 25.15 & 46.09 & 47.11 & 46.6 \\
\hline L.S.D at 5\% & 1.76 & 1.57 & 1.67 & 1.61 & 1.17 & 1.39 \\
\hline
\end{tabular}

Abbreviation: NPK = Commercial fertilizer named Agro-Top (4-5-40).

MO = Mineral oil named folk oil. 
Also, NPK application at $4 \%$ with mineral oil at $3 \%$ increased the percentage of floral bud than sprayed with NPK alone. Furthermore, the other treatments except the control enhanced the floral bud percentage since, control trees present about $46.6 \%$ as a means of both seasons.

These results agreed with those reported by Gabr (1996) Which found that sprayed Le Cont pear trees with Dormex increased the percentage of the developed floral buds. In addition, (Aly et al., 1998) mentioned that Dormex increased floral bud burst percentage. Moreover, EL-Sabrout (2005) reported that spraying Le Conte pear trees with Dormex at $1.5 \%$, mineral oil at $3 \%+$ thiourea at $1.5 \%$ + potassium nitrate at $1.5 \%$ and mineral oil at $3 \%+$ Urea at $3 \%+$ potassium nitrate at $1.5 \%$ treatments gave significant higher floral bud percentage compared with the control. In the meantime, (Stino, 1997) mentioned that Dormex at $1.5 \%$ enhanced floral bud burst and accelerated full flowering of Anna apple. Also, Mohamed et al.(1995) reported that the average percentage of floral buds on one-year-old shoots of Anna apple was increased by Dormex at all experimental dates as well as Urea + Universal on January $6^{\text {th }}$ or $21^{\text {st }}$.

\section{Effect on percent of fruit set and fire blight:}

Data in Table (3) revealed that dormancy-breaking chemicals had a significant effect on the fruit set percentage than the control during the two seasons 2006 and 2007.

From this table it is clear that Dormex at $1 \%$ with mineral oil at $3 \%$ gave the highest significant fruit set percentage since, it presented about 18.8 $\%$ as a mean of two seasons compared with the other treatments. In other words, the control trees had the lowest significant fruit setting and it gained about $4.32 \%$ as a mean of two seasons. The data also reveal that Dormex at $1 \%$ gave a higher effect than spraying trees with Dormex at $2 \%$, that is mainly due to that hydrogen cyanamide is an effective dormancy breaking agent throughout the rest period by synchronizing flowering the chances of effective cross-pollination must be greatly increased, which should have a positive effect on fruit set and yield potential, (Fuchigami \& Nee, 1987).

Table (3): Effect of Dormex, mineral oil and NPK on percent of fruit set and fire blight incidence.

\begin{tabular}{|l|c|c|c|c|c|c|}
\hline \multirow{2}{*}{ Treatment } & \multicolumn{3}{|c|}{ Fruit set \% } & \multicolumn{3}{c|}{ Fire blight \% } \\
\cline { 2 - 7 } & $\mathbf{2 0 0 6}$ & $\mathbf{2 0 0 7}$ & Mean & $\mathbf{2 0 0 6}$ & $\mathbf{2 0 0 7}$ & Mean \\
\hline Dormex 1\% & 10.57 & 10.33 & 10.45 & 0.85 & 0.61 & 0.73 \\
\hline Dormex 1\% + Mo 3\% & 18.03 & 19.57 & 18.8 & 0.00 & 0.00 & 0.00 \\
\hline Dormex 2\% & 7.20 & 5.80 & 6.5 & 1.75 & 1.07 & 1.41 \\
\hline Dormex 2\% + Mo 3\% & 11.43 & 19.30 & 15.37 & 0.00 & 0.00 & 0.00 \\
\hline Mineral oil at 3\% & 8.20 & 9.60 & 8.9 & 4.04 & 3.22 & 3.63 \\
\hline NPK at 4\% & 7.70 & 6.13 & 6.92 & 7.61 & 3.91 & 5.76 \\
\hline NPK at 4\% + Mo 3\% & 5.90 & 5.30 & 5.6 & 10.48 & 6.86 & 8.67 \\
\hline Control & 4.20 & 4.43 & 4.32 & 15.16 & 12.93 & 14.05 \\
\hline L.S.D at 5\% & 0.72 & 1.01 & 0.87 & 0.46 & 0.28 & 0.37 \\
\hline
\end{tabular}

Abbreviation: NPK = Commercial fertilizer named Agro-Top (4-5-40).

MO = Mineral oil named folk oil 
Moreover, (Bester \& North, 1988) found that spraying with hydrogen cyanamide at $1 \%$ about 4 weeks before the start of normal bud break enhanced fruit set on young Sun gold plums with Santa Rosa pollinators.

Whereas, spraying Le Conte trees with mineral oil at $3 \%$ produced higher fruit set than those obtained from trees sprayed with commercial fertilizer each alone or with mineral oil at 3\%, This data is confirmed by (ELGarib et al., 1995) who found that increasing percentage in fruit set was associate with trees which had highest percent values of flower buds in the two seasons.

Regarding to the effect on fire blight the data presented in Table (3) show that all treatments used reduced the percentage of fire blight incidence of trees than untreated ones that is mainly due to that the untreated trees have taken a long duration to induce fruit set. Therefore, the flowering period was so long and the flowers reached the time of infection with fire blight. Also, NPK at $4 \%$ with mineral oil at $3 \%$ gave a higher percentage of fire blight incidence than the other treatments used but almost lower than the control.

Conversely, spraying Le Conte pear trees with Dormex at $1 \%$ or $2 \%$ with mineral oil at $3 \%$ did not show any number of flower infected by fire blight on the tree. This treatment gave $0.0 \%$ that is not astonishing since, the earlier fruit set were resulting from these treatments before the time of infection with fire blight. Furthermore, Dormex at $1 \%$ or $2 \%$ gave a lower percent of fire blight than using mineral oil at $3 \%$ or commercial fertilizer at $4 \%$ each alone or in combination. The obtained data also inagreement with those reported by (Tawfik et al., 2002)

\section{Effect on the content of total sugars, amino acids and phenols in} pear bud trees:

Data presented in Table (4) indicated that dormancy-breaking agents increased total sugars and total amino acids, as compared with the control. The trees sprayed with Dormex at $1 \%+$ mineral oil at $3 \%$ presented higher significant content of bud total sugars and total amino acids since, it gave about $13.9 \mathrm{mg} / \mathrm{g}$ and $3.18 \mathrm{mg} / \mathrm{g}$ respectively as a mean of both seasons. On the contrary, the untreated trees showed a least value in this respect. The obtained results were in accordance with (Stino \& Rashad, 2002) who reported that total sugars was increased with ammonium sulphate and this result may confirm that the high levels of nitrogen in (ammonium nitrate or sulfate) and $\mathrm{H}_{2} \mathrm{CN}_{2}$ treatments resulted in rapid increase in $\mathrm{GA}_{3}$ concentration, which induced an increase in level of total sugars.

On the other hand, the dormancy-breaking chemicals significantly decreased bud total phenols as compared with the control. Yet, Dormex at $1 \%$ with mineral oil at $3 \%$ showed a more pronounced effect. Since; it reduced the content of total phenol than the other treatments used or the control. Furthermore, trees sprayed with mineral oil alone at $3 \%$ gave higher values of total phenol than those sprayed with commercial fertilizer at $4 \%$, but almost lower than the control. That is not astonishing since, Dormex applications hasten bud burst percentage mainly due to their effect for reducing the content of total phenol in buds. 
Table (4): Effect of Dormex, mineral oil and NPK on the content of total sugars, amino acids and phenols in pear bud trees.

\begin{tabular}{|c|c|c|c|c|c|c|c|c|c|}
\hline \multirow[t]{2}{*}{ Treatment } & \multicolumn{3}{|c|}{$\begin{array}{c}\text { Total sugars } \\
(\mathrm{mg} / \mathrm{g})\end{array}$} & \multicolumn{3}{|c|}{$\begin{array}{c}\text { Total amino acids } \\
(\mathrm{mg} / \mathrm{g})\end{array}$} & \multicolumn{3}{|c|}{$\begin{array}{c}\text { Total phenols } \\
(\mathrm{mg} / \mathrm{g})\end{array}$} \\
\hline & 2006 & 2007 & Mean & 2006 & 2007 & Mean & 2006 & 2007 & Mean \\
\hline Dormex 1\% & 12.2 & 12.9 & 12.55 & 2.53 & 2.61 & 2.56 & 8.38 & 8.36 & 8.37 \\
\hline Dormex 1\% + Mo 3\% & 13.80 & 14.00 & 13.9 & 3.13 & 3.22 & 3.18 & 6.46 & 6.41 & 6.44 \\
\hline Dormex 2\% & 12.63 & 13.20 & 12.92 & 3.01 & 3.05 & 3.03 & 7.57 & 7.38 & 7.48 \\
\hline Dormex 2\% + Mo 3\% & 12.70 & 13.00 & 12.85 & 2.92 & 2.94 & 2.93 & 8.18 & 8.13 & 8.16 \\
\hline Mineral oil at 3\% & 10.17 & 11.77 & 10.97 & 1.58 & 1.58 & 1.58 & 9.18 & 9.16 & 9.17 \\
\hline NPK at $4 \%$ & 10.83 & 11.80 & 11.32 & 1.35 & 1.36 & 1.36 & 8.28 & 8.26 & 8.27 \\
\hline NPK at $4 \%+$ Mo $3 \%$ & 10.47 & 10.57 & 10.52 & 1.38 & 1.39 & 1.39 & 8.78 & 8.71 & 8.75 \\
\hline Control & 8.87 & 9.07 & 8.97 & 0.91 & 0.92 & 0.92 & 15.43 & 14.69 & 15.06 \\
\hline L.S.D at $5 \%$ & 0.32 & 0.21 & 0.27 & 0.04 & 0.04 & 0.04 & 0.04 & 0.34 & 0.19 \\
\hline
\end{tabular}

Abbreviation: NPK = Commercial fertilizer named Agro-Top (4-5-40). MO = Mineral oil named folk oil.

The data also revel that the untreated trees gave higher total phenols against the other treatments. Since; it presented $15.06 \mathrm{mg} / \mathrm{g}$ as a mean of two seasons. The obtained results agree with those reported by (Hegazi et al., 1999) who found that Dormex treatments significantly decreased bud total phenols and increased total amino acids. Furthermore, (Fayek et al., 1999) mentioned that total soluble sugars content increased gradually to reach a maximum at the end of bud dormancy of Le-Conte pears bud and continued for a period. This period was shorter in treated buds than control. The same authors suggested that bud burst of Le-Conte pears after termination of endodormancy appeared to require an increase in total soluble amino acids. They also reported that total soluble phenols reached the lowest level just before bud break. Moreover, (El-Sabrout, 1998) found that Dormex treatments significantly decreased bud total phenols but increased bud total carbohydrates and total amino acids, as compared with the control of Flame seedless grapevines.

\section{Effect on number of fruit, fruit weight and yield:}

The results from Table (5) indicated that all treatments used significantly increased the number of fruit per tree than the control. Moreover, Dormex application at $1 \%$ or $2 \%$ with mineral oil gave a higher number of fruits per tree than the other treatments used. Also, Dormex application at $1 \%$ gave a higher number of fruits than those treated with mineral oil at $3 \%$ or commercial fertilizer at $4 \%$ each alone or in combination. From this table it is clear also that all treatments used significantly increased the weight of fruit than the control. Furthermore, Dormex at $2 \%$ or NPK at $4 \%$ with mineral oil significantly increased the average fruit weight than the other treatments. Yet, trees sprayed with mineral oil at $3 \%$ gave a lower fruit weight than the other treatments used but almost higher than the control.

With regard to the effect of Dormex, mineral oil and commercial fertilizer on yield per tree, data from Table (5) showed that Dormex at $1 \%$ or $2 \%$ with mineral oil at $3 \%$ increased the yield per tree significantly than the other treatments used. The increment due to these treatments is due to their effect for increasing the number of fruit per tree. Whereas, no clear effect was 
obtained on yield per tree between trees sprayed with Dormex application at $1 \%$ or $2 \%$ alone or sprayed with NPK at $4 \%$ each alone or with mineral oil at $3 \%$ but, these treatments gave a higher significant effect on yield per tree, that was in agreement with (Kliank et al., 1991) who indicated an increase in fruit production as a result of application of hydrogen cyanamide on Nashi pear. Also, (Thoronton, 1989) on apple cultivars grown in Peru indicated that yields were much higher after application of Dormex $2-5 \%$ after pruning. Moreover, (Jackson \& Bepete, 1995) found that Cyanamide application significantly increased fruit yield in most of the cultivars. This effect on yield was entirely a result of increased flowering and fruit set.

On the other hand, Le Conte pear tree sprayed with mineral oil alone at $3 \%$ gave a lower yield per tree than the other treatments used but higher than the control. Since, the reduction attributed for this treatment is mainly due to that mineral oil gave a lower fruit weight than the other treatment used under this study. The obtained data go in line with (North et al., 1990) on almond, (EL-Shazly, 1999) and (Roan et al., 1997). Furthermore, (Tawfik et al., 2002) found that mineral oil and $\mathrm{K} \mathrm{No}_{3}$ were effective treatments for increasing yield of Le-Conte pear trees

Table (5): Effect of Dormex, mineral oil and NPK on number of fruit /tree, fruit weight and yield of Le Conte pears.

\begin{tabular}{|c|c|c|c|c|c|c|c|c|c|}
\hline \multirow{2}{*}{ Treatment } & \multicolumn{3}{|c|}{ Number of fruit /tree } & \multicolumn{3}{|c|}{ Fruit Weight (gm) } & \multicolumn{3}{|c|}{ Yield (Kg/tree) } \\
\hline & 2006 & 2007 & Mean & 2006 & 2007 & Mean & 2006 & 2007 & Mean \\
\hline Dormex 1\% & 515.0 & 514.7 & 514.8 & 211.8 & 214.0 & 212.9 & 109.1 & 110.1 & 109.6 \\
\hline Dormex $1 \%+$ Mo 3\% & 551.3 & 548.3 & 549.8 & 216.6 & 220.3 & 218.5 & 119.4 & 120.8 & 120.1 \\
\hline Dormex 2\% & 487.7 & 482.3 & 485.0 & 212.7 & 216.9 & 214.8 & 103.7 & 104.6 & 104.2 \\
\hline Dormex 2\% + Mo 3\% & 520.0 & 530.0 & 525.0 & 221.0 & 227.3 & 224.2 & 114.9 & 120.1 & 117.5 \\
\hline Mineral oil at 3\% & 483.3 & 488.7 & 486.0 & 194.7 & 193.7 & 194.2 & 94.1 & 94.6 & 94.4 \\
\hline NPK at $4 \%$ & 497.0 & 492.3 & 494.7 & 212.1 & 215.1 & 213.6 & 105.4 & 105.9 & 105.7 \\
\hline NPK at $4 \%+$ Mo $3 \%$ & 476.3 & 473.7 & 475.0 & 221.5 & 228.0 & 224.7 & 105.5 & 107.9 & 106.7 \\
\hline Control & 371.0 & 376.3 & 373.7 & 165.7 & 167.3 & 166.5 & 61.5 & 62.9 & 62.2 \\
\hline L.S.D at $5 \%$ & 3.37 & 3.02 & 3.19 & 3.51 & 4.28 & 3.89 & 1.10 & 1.57 & 1.34 \\
\hline
\end{tabular}

\section{REFERENCES}

Aly, M. M.; H., Kabeel and G. L., Elwaia (1998). Effect of some dormancy breaking treatments on some plum cultivars in Giza and Kalyubia Governorates. J. Agric. Sci. Mansoura Univ., 23 (7): 3301-3316

Bester, M. and M., North (1988). Cyanamide application on Sun Gold plumspreliminary. Deciduous fruit grower, 36 (11); 457.

Dubey, R. S. and M. Rani $\left(1989_{a}\right)$. Influence of $\mathrm{NaCl}$ salinity on growth and metabolic status of protein and amino acids in rice seedlings. J. Agron. Crop Sci., 162: 97-106.

Dubey, R. S. and M. Rani (1989b). Salinity induced accumulation of freamino acids in germinating rice seeds differing in salt tolerance. J. Agron. Crop SCi., 163: 236-247. 
El-Gharib, S. El-Banna; S. A., El-Shall and B. A., Shahin (1995). Effect of dormant season spray applications on growth and fruiting of Le-Conte pear trees. Acta Hort., 409: 207-213.

El-Sabrout, M. B. (1998). Some physiological an biochemical response of Flame seedless grapevines to hydrogen cyanamide (Dormex) spray. Alex. J. Agric. Res., 43 (3): 167-185

El-Sabrout, M. B. (2005). Effect of some dormancy - breaking chemicals on Le-Conte pear trees. J. Agric. Sci. Mansoura Univ., 30 (3): 1595-1616.

El-Shazly, S. M. (1999). Effect of hydrogen cyanamide (Dormex) spray on bud behavior, growth, yield, fruit quality and leaf composition of Thompson seedless grapevine. Alex. J. Agric. Res., 44 (2): 221-235.

El-Sheikh, A. A. (2000). Study on the effect of two dormancy breaking agents on Anna apple trees. J. Agric. Sci. Mansoura univ., 25 (11): 7089-7096

Erez, A. (1987). Chemical control of bud break. Hort. Sci., 22 (6): 1240-1243.

Erez, A.; S. Y., Wang and M., Faust (1997). Lipids in peach buds during dormancy, a possible involvement in dormancy control. Adv. Hort. Sci. 11: 128-132.

Fayek, M. A.; W. A., Abd El-Wahab; S. M., Mohamed and T. A., Fayed (1999). Changes of some chemical components of pear buds in relation to bud break. Proc. $1^{\text {st }}$ Congress on Recent Technologies in Agriculture, Cairo University, Faculty of Agric., (1): 63-70.

Foot, J. H. (1987). Effect of hydrogen cyanamide on bud emergence in wine grapes. Calif. Agric., 41: 19.

Funchigami, L. H.; C. L. Weiser; K., Kobayshi; R., Timmis and L. V., Custa (1982). A degree growth stage (GS) model and cold acclimation in temperate woody plants. P.93-116. In P. H. Li and A. Sakai (eds). Plant cold hardiness and freezing stress. Vol. 2. Academic, New York.

Gabr, N. I. E. (1996). Effect of hydrogen canamide (Dormex, $\mathrm{H}_{2} \mathrm{CN}_{2}$ ) on breaking rest of buds, flowering, vegetative growth, yield and fruit quality of Le-Conte pear trees. M. Sc. Thesis, Fac. Agric, Alex. Univ.

Harminder, S. and S. S., Mann (2002). Effect of hydrogen cyanamide and thiourea on bud burst, flowering and fruit set in pear cv. Pathernakh. Indian J. Hort., 59 (1): 49-51.

Hegazi, A.; N. R., Samra; S. A., Mehana and A. A., Sallam (1999). Effect of Dormex and Urea application of flowering, yield, hormone content and bud histology of Anna apple trees. Zagazig J. Agric. Res., 26(1): 95106.

Jackson, J. E. and M., Bepete (1995). The effect of hydrogen cyanamide (Dormex) on flowering and cropping of different apple cultivars under tropical conditions of sub-optimal winter chilling. Scientia Hort., 60: 293304.

Klinak, D. J.; H. R., Rohitha and J. C., Peveral (1991). Use of hydrogen cyanamide to improve flowering and fruit set in Nashi (Pyrus serotina Rehd.). New Zealand Jour. Of Crop and Hort. Sci., 19: 87-94.

Kurdo, H.; S., Shonosuke and C., Kazuhiko (1990). Seasonal changes in peroxidase - scavenging systems of apple trees in relation to cold acclimation. J. Jap. Soc. Hort. Sci., 59: 229-308. 
Mann, S. S.; H., Singh; A. S., Sandu and G. P. S., Grewal (1994). Effect of cyanamide on bud burst, flowering and fruit maturity of Baggugosha pear. Acta Hort., 367:214-223.

Mazumadar, B. C. and K., Majumder (2003). Methods on Physico-chemical Analysis of fruits. Calcutta Univ., Tri Nagar, Delhi, 124-125.

Mohamed, S. M.; W. A., Abd-EL-Wahab; M. A., Fayek and T. A., Fayed (1995). Effect of some chemical treatments on "Anna" apple flower bud scales and differentiation in relation to sugar content. Zagazig J. Agric. Res., 22 (3) 881-893.

Mokhtar, H.; E. M., EL-Fkharani and R. G., Stino (1994). Effect of hydrogen cyanamide on flowering and yield and fruit quality of some Asian pear cultivars grown in Egypt. Egypt J. App. Sci. 9: (3) 140-159.

Nir, G. and S., Lavee (1993). Metabolic changes during cyanamide induced dormancy release in grapevines. Acta. Hort., 329: 271-274.

Nonhebel, H. M.; T. P. Cooney and R., Simpson. (1993). The route, control and compartmentation of auxin synthesis. Aust. J. Plant Physiol., 20: 527-539.

North, M.; J. G. M., Cutting and G., Jacobs (1990). Effect of the rest breaking agent cyanamide on cytokinin levels in apple shoots and buds. XXIII, International Horticulture Congress. P. No. (4216).

Ramina, A.; M., Colauzz; A., Masia; A., Pitacco; T., Caruso; R., Messina; G., Scalabrelli; L. E., Powell and S., Lwahori (1995). Hormonal and climatological aspects of dormany in peach buds. Acta Hort., 395: 3546.

Rashad, M. H. (1993). Physiological studies on the metabolic activity of some Rosaceae leaves. Ph.D thesis, Plant Physiology, Fac. Of Agric., Cairo Univ..

Roan-Sufeng; Ni-Wantin; Roan-SF; Ni-WT; Chen-Yungwu (ed.) and ChangLin Ren (1997). Effect of time of nitrogen application on growth of sand pear (Pyrus pyrifolia (Burm. F.) Nakai.). Proceedings of a symposium on enhancing competitiveness of fruit industry, Taichung, Taiwan, District-Agricultural-Improvement-station., 38: 215-222

Sadasivam, S. and A. Manickam (1996). Biochemical method, second edition, New age international. India.

Shahin, B. A. ; S. E., Bahlool and H., Mokhtar (1997). Dormancy breaking of El-Dorado plum trees with chemicals. J. Agric. Sci. Mansoura Univ., 22 (11): 3887-3894.

Snedecor, G. W. and W. G., Cochran (1980). Statistical methods. $7^{\text {th }}$ edition lowa state Univ. Press, Lowa, USA.

Sourial, G. F.; M. H., El-Khali; A. S., Abdel-Aziz; T. A., Abou Sayed Ahmed and A. A., Tawfik (1993). Response of Banaty grapevines to some thiourea treatments. 1 - Time of bud burst, flowering and berry ripening. Zagazig J. Agric. Res., 20 (5): 1593-1599.

Stino, R. G. (1987). Effect of some chemicals on defoliation and floral bud activity of Le Conte pear trees. M. Sc. Thesis, Fac. Of Agric. Cairo Univ. 
Stino, R. G. (1997). Response of Anna apple trees to some treatments with hydrogen cyanamide, mineral oil and their combinations during the dormant season. Egypt. J. Hort., 24, (1): 43-57.

Stino, R. G. and M. H., Rashad (2002). Effect of some nitrogenous compounds, mineral oil, chilling and G. D. D. on Le-Conte pear bud activity in north Egypt. Zagazig J. Agric. Res., 29 (5): 1529-1557.

Swindeman, A. M. (2002). Fruit packing and storage loss prevention guidelines. Washington State University-Tree Fruit Research and Extension Center, Article, page 1 of 9.

Tawfik, A. E.; S. A. El-Shall; A. I. Hanna; A. A., Comah; L. A., El-Ghareeb and S. M., Mahmoud (2002). Efficay of bactericides and dormancy-breaking agents on the incidence of fire blight and fruit production of pear in Egypt. Annal Agric. Sci., Ain Shams Univ., 47 (1): 389-405.

Thornton, J. (1989). First experiences in Peru with hydrogen cyanamide (Dormex) on apples. Acta Hort. 232: 116-119.

Van Loon, L. C. and A. Van Karmen (1967). Polyacrylamide disc electrophorsis of the soluble leaf protein from Nicotiana tabacum Var Samsum and Sansum. Phytochem., 7: 1727-1735.

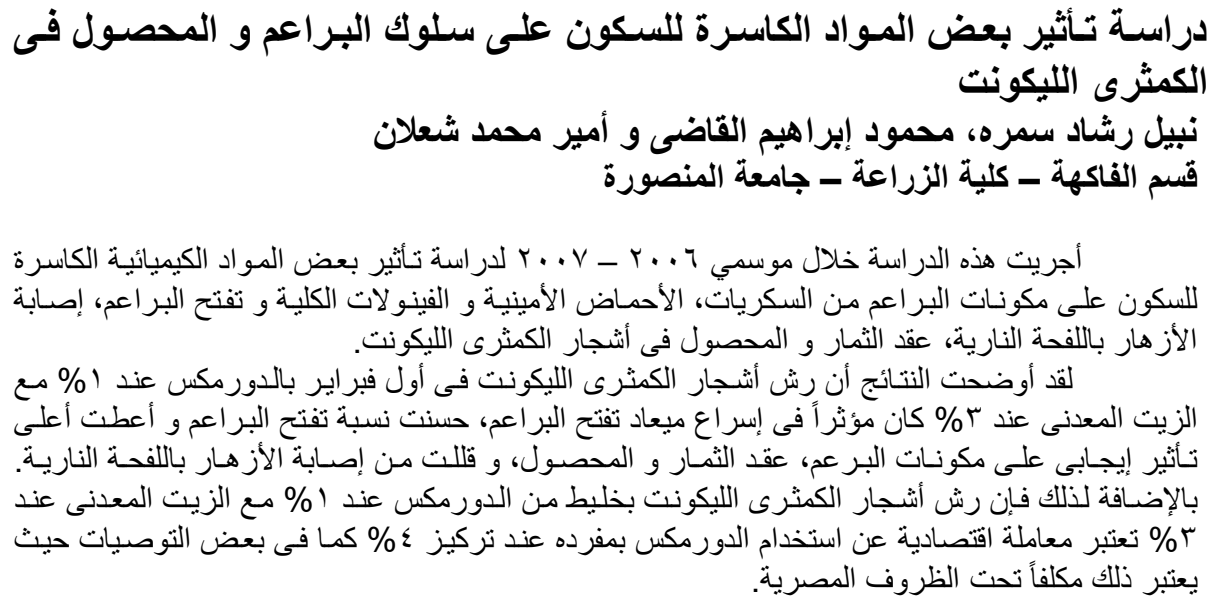

